\title{
Women and peace initiative in Igbo traditional society: A viable option for peace building in modern Africa
}

\author{
Okoro, Kingsley N. \\ Department of Philosophy and Religion Ebonyi State University, Abakaliki, Abakaliki—Ebonyi State, Nigeria
}

Email address:

okoro_kingsleyn@yahoo.com

\section{To cite this article:}

Okoro, Kingsley N.. Women and Peace Initiative in Igbo Traditional Society: A Viable Option for Peace Building in Modern Africa. Humanities and Social Sciences. Vol. 1, No. 1, 2013, pp. 58-69. doi: 10.11648/j.hss.20130101.17

\begin{abstract}
Peace, the pristine aspiration of humanity seems to have evaded the contemporary age. Therefore, bloody conflicts have ravaged human race from dateless past to the present. However, humanity has attempted to put in place certain socio-political mechanism to grapple with this insidious phenomenon. In spite of the various mechanisms, war has continued to persist with greater intensity. Experts attributed its persistence to human greed, personal enterprise and violation of certain social capitals. Africa which had track record of peaceful estate in her traditional history is now synonymous with conflict in modern history. Thus, she is described as one of the most volatile part of the world. Consequently, world communities have become concerned on how to stop or at least reduce it to the barest. Therefore; many have come up with propositions as to the cause of conflict in this region and consequently suggested steps to stopping it. However, this work has taken historical, socio-political and cultural approach to the study of conflict in this region. It found that the recent upsurge of conflict in Africa is predicated on the fact that certain social values and norms have been violated. The basic institution sustaining the social structure have been neglected and abandoned. This paper also discovered that one major cause of the upsurge of conflict in Africa is the dislodging of the women from the public sphere and her abandonment of her divine role.. We therefore underscore that if peace must return to Africa, women must return to their legitimate social role. We used the Igbo example to justify our assumption.
\end{abstract}

Keywords: Women, Peace Initiatives, Igbo, Society, Option, Modern Africa

\section{Introduction}

Sweet is war to whom who knows it not ( Castilena 1922:110, Bainton, 1982 25). The terror of war and violent conflicts is classically pictured in this ancient poem thus, 'Groaning within; without a net is spread, Gripping the towers about: Man strikes man dead: And inarticulately, like beast in dread, mother and infants cry. And blood runs red. Running they rob, they fly (Acselylus 1980:345-51). War and bloody conflict, though the constant experiences of humanity in history have been derided by every generation. However, it seems that this social phenomenon has become an inescapable lot of man in society. Thus, history is dotted with the plagues of bloody conflicts as families bemoan the losses of both human life and material resources after each war experience.

The ferocity with which this insidious social phenomenon has plagued humanity differs from one generation to the other. However, the insidious upsurge of war and violent conflict both in International and continental level in the $21^{\text {st }}$ century calls for a critical rethinking by all rational persons. Africa as a region seems to be the worst hit and its effect in her is quite untold. Remonstrating on the effect of bloody conflict in Africa, Muntanga (2007) writes, 'violent conflicts have caused untold suffering in Africa. There are 17 ongoing conflicts in Africa, which are at varying degrees of form and intensity. The horn of Africa particularly and the great lake region have been the location for some of the deadliest and most protracted of these conflicts, both inter-state and intra-state conflicts (366). Consequently, this constant upsurge of bloody conflicts in Africa has wasted great number of her population, disorganized the society, created massive poverty and suffering, delayed her development, and summarily described as headless venture at certain quarters. Herodotus has shown the irrationality of engaging in bloody conflicts as he says, 'No one is so foolish as to prefer war to peace in which instead of sons burying their fathers, fathers bury their sons... ( Bainton 1982:25). 
However, the irrationality of violent conflict notwithstanding, man has continued to regard conflict as irreversible social situation in which humanity must accommodate willingly. Thus, conflict is defined as a social phenomenon that is an indispensable part of human existence (Ademola 2007:35). Conflict is a natural part of our daily lives (Weeks 1992:XI, Ademola, 2007:35).though, conflict has been described as indispensable in human society, nevertheless, humanity in general has made frantic efforts to end this social phenomenon and to live in harmonious society. The desire to end all conflict in history gave birth to social theories of Marx, Rousseau and Hobbes. As for Rousseau, it was man's insatiable desire and greed that gave birth to social conflicts. He spotlighted on the ownership of private property as the sole origin of social conflicts. Hobbes on his own argues that in the state of nature, conflict was an inseparable part of the social arrangement. Therefore to end it man entered into social contract ( Ibeanu 2007:5).

However, the current reoccurrence of violent conflict both in global and regional scales casts doubts on the authenticity of Hobbes social theory, noting that the contemporary socio-political system is organized around the theme of social contract. Great alliances of comity of nations at all level of social polity have been entered, yet humanity has not been spared of this insidious social phenomenon-violent conflict, rather man experience it in greater intensity. Uka (2005) laments this contemporary war experiences of man as he remarks thus, ' We live in a turbulent world, marked by violence which manifests its self in manifold forms, such as terrorist attack, bomb blasts, wars, massacres, ethnic cleansing, cultural genocide and atrocities on women and tribal minorities' (1). Against the backdrop of Uka's observation, we subsume that with current ferocity of conflict in the $21^{\text {st }}$ century, humanity is at the threshold of obliteration ( Okoro, 2008:291). Notably, one of the major characteristic of $21^{\text {st }}$ century is suspicion amidst all alliances. Thus, nations and people are suspicious of each other, truces are broken with recklessness and social mistrust is the order of the day. The consequence therefore is that in all sphere of existence are threatened and have become threatening (Okoro 2008:291).

Against the background of the mordant social situation, this paper is dedicated to studying the role of women in midwifing peace in the traditional Igbo society. This is with the aim of finding how that model could be a viable alternative in peace building process in modern Africa. It thus underscores that the contemporary violent conflict is attributable to the avid neglect of the traditional role of women in the peace initiative. Women occupy a preponderant position in the socio-political arrangement of every society (Okoro, 2007:172). Though men make the rules governing the social order, it is only the women who are capable of humanizing these social rules and bring harmony and peace to entire mankind (Chattopayay 2008:1-6). Contemporary sociological studies have revealed that women have unique opportunities for conflict resolution due to the unique role they play in the society and their natural affinity towards peace building. Thus, Mutanga (2007) notes that women in diverse cultures have proven themselves to be able to bring about peaceful solution where men have failed (369). Therefore, Kusa (2007) describes women as inherently peaceful and as such capable of teaching and preserving peace (234). This work underscores the basic fact that womanhood, being the symbol of self sacrificing love is fundamental to maintaining world peace (Okoro, Alternative Feminism 2008:189). Thus, if women re-venture into the public sphere in Africa, they would take the men- their childrenby storm and reduce militarism to nothingness in a very short time, more especially in Africa. Upon this assumption this work is designed and embarked on

\section{Peace in Perspective}

Most often peace and war are viewed as inseparable social variables, hence peace is regarded as converse of war. Therefore, we hear of war and peace as being two sides of the same coin ( Ibeanu 2007:3). Collorary to the above assumption, peace is generally defined as the absence of war and as such world peace is conceived in relation to war ( Okoro, 2008:294). Thus Bainton (1992) writes, in as much as the ethic of just war in antiquity was conceived in the framework of peace, the concept of peace affords the best point of departure (12). Notably, the departure, which Bainton 's framework of analysis indicates does not however nullify the assumption, that generally the meaning of peace is not understood, especially in the ancient times, in relation to war (Okoro 2008:295). However, Bainton's framework indicates different meaning ascribed to the concept of peace that has affected our understanding and treatment of peace in the contemporary literature.

A review of the dominant cultures that gave birth to modern civilization will at this point aid us in understanding how the concept of peace has developed over time. Beginning with the Hebrew culture, we notice that peace was understood in a holistic mode and it embraced all facets of human existence (Gerhard 1938:10). Thus for the Jews, peace is the absence of war. The peace metaphor was developed from the idea of (שָלכ) Shalom, which signify prosperity. this idea is clearly expressed in Psalm 123 thus: 'Thy wife shall be fruitful vine...thy children olive branches...peace upon Israel'. Peace in this civilization connotes security and as such the word 'שַׁלן is a demeanor of impregnable fortress, hence the city Yeru'shalom Jerusalem (Gerhard, 1938:10).

In Greek tradition, the word 'errene' is central in understanding of peace concept. Errene is rooted in the idea of 'human-linkage'. Thus peace is conceived in this culture as the state of order and coherence and not merely the absence of war and distress (Bainton, 1992 17). Comparatively, the conceptual analysis of peace therefore reveals a wiry difference between the Hebrew and Greek 
understanding of the concept (Okoro, 2008:295). Notably, in Greek culture, peace embraces but not limited to prosperity. In the words of Bainton (1992), '...if peace were not identical with prosperity, at any rate peace begat prosperity and was commonly accompanied in artistic representation in vivid terms as the cornucopia (17). Against this background, Myre (1927) underscores the basic fact about Greek understanding of peace thus:

The philosophers engage in lengthy quest to know the good and whom it may be found, virtue, reason, much else, they say, I learnt it by digging up the ground. Peace is from the kindest Goddess, bestower, dearest Zeus of every treasure, wedding, kindred, children, friends, wealth, health, wheat and pleasure (142)

The Greek philosophers see peace therefore as a natural, original, God-given state of human existence. Peace in this philosophical culture is the pre-corruption state of man in the society, as god established it. Hence peace is a state of perfection, an earthly expression of God's kingdom ( Ibeanu 2007: 5). The Greeks Just as the Hebrew locate the origin of peace beyond the material realms. Peace is the priceless gifts of the Gods. It suffices therefore that peace is incidental to human creation. Peace thus is not the creation of laws, edicts, canons and judicial system. It is not a legislative matter, rather an interface of divine human relationship. In line with this conception of peace, Khan (2008) attributes the loss of this pristine divine gift in the contemporary world to the loss of relationship with God as he writes,

Now mankind finds itself on the threshold of new era, with technological progress, we are now able to find new world prosperity... a new better world but at the same time, we see violence in the world. This unhappy state of affairs deems to nullify all our scientific progress (27)

In Roman culture peace was defined as the absence of war. This idea is couched in the concept of 'Pax Romana', which means Roman peace. This idea was derived from the word 'pact' Pact technically means 'covenant' or an 'agreement' not to fight, hence the association of 'Pax Romana' with tranquility ( Okoro,2008:296) Pax Romana is also understood as quies otuim (repose) as well as securitas (Bainton 1992:18). However, the Romans just as the Hebrews and the Greeks, still underscore the fact that peace is the main source of abundance.

Overtly, the ancient traditions as reviewed above maintain unambiguously that peace is religio-cultural phenomenon. Thus the Romans as well as the Greeks personified and deified peace. On the contrary, the Hebrews objected to the deification of peace or any other thing whatsoever due to their belief on and practice of absolute monotheism (Bainton 1992: 20). Both the Romans and the Greeks have had gods for all man's major concerns. In these traditions, there were gods for peace and war. Eirene and Pax were the gods of peace for the Greeks and Romans respectively. The gods of war were Ares for the Greeks and Maxs for the Romans. Both the Greeks and the Romans erected alters for both the gods of peace and that war.

Peace had an immeasurable value in the ancient world. In fact, it was a priceless commodity desired by all nations and peoples of then world. Though, due to the insatiable human greed and cupidity, wars and bloody conflicts and both military and civil militarization dotted the ancient sociological and political history. However, the Spartan war history taught the ancient world indelible lessons about war and militarization ( Okoro, 2008:297). One of the great lesson the Spartan's war history taught the ancient world, which is still relevant for the present age is that war, bloody conflicts and militarization are capable of annihilating human life from the world.

Against this background, the ancient world made frenzied attempt to redefining the concept of peace in relation to environmental friendly projects, aimed at sustaining human lives. This paradigm, defined categories that were more human and relational as against the Hobbesian category in the state of nature, 'where might is right'. Consequently, some of the ancient deities, which were war-like, began to be identified with peace. The Greecio-Roman deities gradually grew peaceful and encouraged human peaceful co-existence. Bainton (1992), sustains this assumption as he writes:

some of the deities, once war-like grew peaceful, Hercules developed from Goliath of Dorrian to be suffering servant of humanity, enduring colossal labours to free the world of monsters and befriend mankind. Athena, the protector of Athens appeared at first armed with helmet, lance and shield but with cultural development of the nation, She became the patroness of learning, the fluttered owl of her battles, were transformed into sadete symbol of wisdom and her favourite tree, the olive gave its branches as a sign of peace (8).

In fact, history reveals that all the ancient world, with exception of Assyria, had a myth of one time warless state - lost golden age of human history and whose recovery is the object of human desire and endavour. In the GreecoRoman form of the myth, peace had different connotations; hence it was not merely thye bestowal of abundance rather the result of it. Accordingly, in the golden age, each freely yielded her increase without the labour of man. The implication therefore is that in in this lost age, there was no need for private property, no temptation to introduce slavery and no classification of human beings and as such there was no reason to resort to war. Collorary to the above assumption, war resulted because of the lost of the original state of nature. Rousseau gave a positive picture of this state of nature thus:

in the original state of human existence of man in which there are no desires. In that state, man existed as a free, gentle salvage. In that state of nature, man were naturally good., they were born free and had few desires and greed, this undermines this peaceful, pristine state of nature ( Ibeanu 2007: 8). 
Rousseau representing the Greco-Roman and Christian culture, attributed the loss of this faultless state of nature to the insatiable desire and greed of man .The Hebrew culture accounting for the lost golden age of humanity, presented a classical mythology in which disobedience was the sole cause of the golden age. Here, the symbolic Adam and Eve's disobedience introduced conflict between the serpent and the seed of the woman. The murder of Abel by his brother, Cain on the one hand, introduced bloodshed among humanity (Okoro 2008:298).

The appearance of the myth in Greek literature was in the poem of Hessiod, who pictured the golden age of Cronos, when men dwelt at ease, in prosperity and peace. However, with the passage of time, there ensued the progressive deterioration in the world system as it moved from the age of gold to silver and to bronze and followed by the unclassified age or rather the age of iron. Thus in the present age, we notice violence and bloodshed in large scale as families are art odds with each other. This period witnesses unprecedented breakage of truce and oaths. Actually, this period is a reversal of Rousseau notion of the state of nature (Germane 1945:16).

In this direction, the Stoic mythical imagery of the progressive deterioration of the world order into their category of rational order of a cosmos broken by a fall. Arutus, a disciple of Zeno, described the good old days, when man did not yet know war or disputes but lived in a simply estate. According to Arutus, it was in the degenerated age of bronze that the evils of sword were forged, the plow ox eaten and justice took her flight among the stars. Chyrysippus gave a rational explanation of this fall as he says that the gods introduced war in order to check population explosion in the world ( Bainton, 1992:21). Chyrysippus further maintains that that peace and peaceful coexistence are the greatest undoing of the gods, hence the gods needed to provide plenty of goods for great and uncontrollable populations of the world.

Africa as a cultural accretion has developed her concept of peace in the context of traditional agrarian environment. In most African traditional settings, peace was equated with freshness, health, well being, harmony, calm and tranquility (Mbede 2003:27). The absence of such qualities was seen as a sure sign of conflicts, which could be either latent or overt ( Nwoye 2009:4). Notably, it was this harmony and freshness that provide farmers with good crops, fishermen with abundant catches and hunters with enough game ( Mbede 2003:28). Consequently, Africans maintain that where there is food for every one ,world peace reigns in homes and families, clans and tribes. Hence no body had any reason to be envious of any one else, therefore neighbouring communities could live in peace, visit one another during off-seasons and attend marriages and funeral ceremonies (Mbede 2003:28).

Generally, majority of African traditional societies are of the view that harmony, freshness and calm are essentially female imagery or rather properties which nature wittingly bequeathed the female folk with. Thus peace, though without any mythological symbol in African societies, is quite fundamental in their daily existence and interpersonal relationship. The fundamentality of peace in diverse African cultures gave rise to the numerous norms and taboos ranging from filial responsibilities to other social relationship, which aimed at sustaining and cementing social harmonious living in the traditional society. Peace and peaceful co-existence are the substructure that sustain the African socio-political structure. Thus Africans just like the Hebrews made peace an essential part of their greetings and felicitation.. Mbede (2003), using the Cameroonian greeting formula sustain our assumption thus:

Peace seems to be fundamental in every Cameroon cultural universe that when two Cameroonians greet each other, they often ask if there is peace at home.

- Ya me la? -what news from home- for the Bafang

- $\quad$ Tchum te bia? -Do you enjoy peace at home- for the Baham

- Ye mine move or Ye evovoe ere mine we? -Do you enjoy peace at home $>$ do you enjoy freshness at home? For the Bete.

The Igbo people of Eastern Nigeria on the one hand have similar greeting pattern, that at every point of first meeting each day, the first greeting is always in the form of question, Kedu or Kedi ka Ulo di? The question inquires about the general well being of the respondent, which include ones state of mind, physical and mental health and economic well being and the state of the family and neighbours. Thus we subsume that peace is an essential property of African societies.

In all the cultures reviewed, peace could be summarily defined as the absence of war, fear, conflict, anxiety, suffering and violence. Hence Francis (2007) avers that peace is primarily concerned with creating and maintaining a just order in the society and the resolution of conflict by nonviolence means (17). Francis further maintains that the interdisciplinary study on peace has revealed six standard meanings of peace, which could be wholly or partially adapted in the socio-historical study. These six paradigms are enunciated thus:

- $\quad$ Peace as absence of war-absence of direct violence

- Peace as justice and development-absence of structural violence

- Peace as respect and tolerance between people

- Peace as gaia -balance in and with the ecosystem

- Inner peace - spiritual peace

- $\quad$ Peace as wholeness and making whole (17-18)

\section{The Concept of Peace Building/Peace Making}

Peace building as a major concept in conflict resolution and management has been defined as, a means of preventing the out break, reoccurrence or continuation of armed conflicts and as well as emergences in a wide range of political, developmental, humanitarian and human right 
mechanism ( Karame 2004:12). Therefore, the process of peace building encompasses all the stages of conflict, from the pre-conflict to the post conflict phase, with aim of laying the basis for sustainable peace in conflict torn society.

Whereas, peace making is concerned with intervention of elite in the decision making level, peace building is centered on the social, economic and psychological universe of the ordinary people at the grass root( Karame 2004:12). Actors in the peace building process are recruited from all levels of the society. A viable peace mission, therefore could be understood as meeting place where people, both men and women of differing cultural background will come together and function together in order to fulfill the mandate of maintaining a sustainable peace agenda in the community ( Report 2002:53). Accordingly this UN report on women, peace and society makes distinction between formal and informal activities within peace process ( Report 2002:58). The report concludes with warning, preventive diplomacy, conflict prevention, peace-making and global disarmament. Conflict resolution, peace negotiation, reconciliation, reconstruction of infrastructure and the provision of humanitarian aids fall under the universe of formal peace process, which is conducted by political leaders, military and international organizations. This aspect of peace initiative also attracts the attention of regional and subregional organizations as well as government and nongovernmental and humanitarian organizations (Karame,2004 :12-13).

In the formal peace building process, women constitute the minority, especially at decision-making levels. However, Olsson (2001) notes that some minor exceptions to this general observation of minimal participation of women in formal peace process in the modern world (98). In her own words, 'the sole notable exceptions today have been the UN peace mission in Namibia ( $40 \%$ women) and South Africa ( 50\% women) (98-100). She underscores the fact that what motivated the high share of women in these peace mission is the ambition of both the special representative of the Secretary General, Marti Ahtisaari and because the mission included large number of civilians (98-110).

On the other hand, the informal peace process activities include but not limited to the following:

- $\quad$ Peace march and protests

- International group dialogue

- The promotion of inter-cultural tolerance and understanding

- The empowerment of ordinary citizens in economic, social cultural and political spheres (Olivia, Bexley Warnock, 1995 :65-70)

At this level of peace building, actors may come from various organizations - International, Regional, Nationals, and Grass roots. The contributions of peace actors at the informal peace process provide an avenue for non- experts in peace studies, to broker peace at various levels of the society. Thus, the women, men, religious groups, and other concerned individual participate in the peace building process at this level. According to Jeane (1995), the informal level of peace building is the main field of women involvement (16). Therefore, women have been noted to be active at the grassroots of peace building, however quite absent (with some modern exceptions) at the formal level of peace building in modern Africa. Consequently, this work aims at re-imaging and re-venturing the modern Africa women into the public sphere of formal peace building process. The Igbo traditional model shall be adapted as a viable model for this project.

\section{The Place of the Women in the Socio-Political Arrangement of Igbo Traditional Society}

Igbo women in the pre-colonial era had direct involvement and considerable interest in the public sphere, which is defined as the socio-political arena through institutional provisions (Odoemena 2008:1). The advent of colonialism placed the Igbo women at the fringes of sociopolitical arrangement. Colonialism diminished the status of the women in Igbo community. This situation caused untold hardship to the Igbo nation. The consequence therefore is war, bloody conflicts, marginalization, oppression and militarization.

However, a re-xamination of the traditional political sociology reveals the obvious fact that women had had a prominent role in the daily administration of justice, which promotes public peace in various Igbo communities. Thus, Ejimofor (1989) describes the Igbo socio-political system as cephalous and stateless, primary democracy, segmentary and decentralized (12-14). The description above points to the fact that the Igbo society had 'varieties of political organization and each are completely capable in all ramifications of fulfilling all the functions of the society ( Nwachukwu 1993;43, Odoemene, 2008:8). These organizations stratified according their gender lines, as the Igbo people had never been gender neutral in allocation of roles-social, economic, and political, though the role differentiation in Igbo traditional society is relatively limited or rather silenced (Odoemene, 2008:8). Therefore, in this socio-political arrangement there is no form of state socio-political organizations that dominate the rest. In this arrangement politics, economics and social life are fused into a unitary societal whole.

Against this backdrop, the control and socialization functions designated after as political functions are conducted by and through non-political structure. Hence political analysts, who were au fait to dealing with societies in which there were differentiations in the socio-political structure, were unlikely to find prototype they usually find in other non Igbo societies. Since such analysts do no examine the non-political roles of women, they became unaware of the consequence of these activities, where 
politics is fused with other aspects of social life ( Odoemene 2008:8-9). The obvious consequences of this oversight have created the need to making clear classification of the status and role of women in the traditional Igbo society.

History reveals that the Igbo people have been predisposed to democratic and egalitarian social arrangement, which accorded a degree of autonomy to womenfolk (Ifemesia, 1979:24). Accordingly, women in the Igbo socio-political arrangement were ensured through the 'dual-sex' political system. This system guarantees that each sex manages its own affairs and had its own kingship institution, age-grade, and secret and title societies (Afigbo,1972:16, Odoemene 2008:9). These groups and institutions of each sex exert recognizable influence upon the society. The system 'dual sex' political arrangement warrants women and men to carry out their responsibilities without infringing on the others' territory. Through this dual-sex' system, which the community has accepted, women were actively involved in the sociopolitical life of their community. This participation was to a certain degree limited to individuals, but as women group, they remain viable social force. Hence Uchendu (1993) underscores the fact that Igbo women were political important and relevant in the scheme of things (17). Anyakaoha (2008) substantiates the same fact as she writes, 'Women in the Southeast Nigeria wield enormous powers by virtue of their position as daughters of the linage (2). Upon the strength of the fore going assumption, Ene (2008) writes, 'However, the paternalistic propensity of African culture, especially, the Igbo Culture does not indicate subjugation of women. On the contrary, women in traditional Igbo societies are forces in political, legal and social issues long before the colonialist arrived in Africa and even during and after colonialism, women have been a powerful part of the Igbo society (12).

The fore going assumption is further sustained by Odoemene (2008) as she opines that the Igbo women are credited with immense power, which they use to control the men (10). Accordingly, women's power is used careful and consciously to control and subjugate the male folk in the traditional society (Odoemene 2008:10) and consequently make men pliable to women's bidding. Notably, Chinweizu (1991) among other cultural scholars, locates the place and role of women at the nave of the Igbo society (16). Thus collier (2004) affirming with Chinweizu (1991) shows that women are purposefully social and political actors in whose activities one can find patterns and regularities (26). Collier (2004), therefore argues further that such regularities can not be explained by looking at moral injunction or jural rules, both of which stress women's subservient position but become intelligible only if women are seen as actors, whose efforts to control the social environment are channeled by cultural rules, by available resources and the choice of others within the social system (90).
In the traditional Igbo political system, women had their own meeting or assemblies and such congregations have been pictured as the base of women political powers. According to Odoemene (2008) women formal leadership roles by which they become politically significant in the traditional society were at two inter-related levels, namely, 'Umuada and Otu-alutaradi levels (11). The former refers to the exogamous union of daughters married away to other villages but retain their ties with their communities of birth. Ene (2007) further describes Umuada as the collectivity of all daughters of a particular clan, village, town or state, whether old, young, single, married, separated or divorced. $\mathrm{He}$ maintains that it is the inalienable right of every daughter of a particular place, without exception to belong to otu umuada, 'the society of native daughters (1-2). In the same vien, Otu-alutaradi refers to the wives of men in the village, who have come from diverse socio-cultural backgrounds (Green,1964:216-232). Wolpe (1974) collaborates this fact as he writes, 'women formed societies based upon membership not only in the villages into which they were married but also in those into which they were born (35). Against this backdrop, Dine (1983) asserts that both groups maintain order, promote life, and bring consolidation, joy, and solidarity among themselves and to the village community (130). Obviously, women associations, which had pre-colonial and ancient roots, gave the Igbo women strong and powerful voice and symbols.

Another pre-colonial socio-political institution among the Igbo nation that recognized the worth of women was 'the village assembly', which was open to all adults, who chose to attend and participate. Indeed, the institution epitomizes the Igbo public sphere and the matters discussed in the arena were such that concerned every one (Odoemene, 2008:11). It is noted that men were more likely to be visible and noticeable than the women in such gathering, however, old women were frequently noticed and were respected, age being one factor, which mitigate sex differences (Fried 1975:72).

Overtly, the leaders of the village assembly were both the men and the women, who above all possessed sense of moral integrity, human personality and bequeathed with high degree of traditional wisdom. Green (1964) in her critical study of the Aba women riot (war) of 1929 substantiates to the massive political and social powers of the Igbo women. Her findings show that the otu-alutaradi provided the Igbo women with collective barging powers to safeguard against excess of male dominance and to deal with men, who jeopardize women interests (169). In this regard, Odoemene (2008), in her critical appraisal of the inter-relationship between the domestic and public spheres, subsumes that the contributions and agencies of women in the public spheres are quite significant (11). She submits that the role of the women in the private sphere crisscrosses and sets the parameter of assessment of the activities that took place in the public spheres.(11). Thus in addition to being part of the process which sets the parameter of public 
life, Igbo women operated as political strategists within the family, the neighbourhood and as well as among their female kinspeople (Odoemene, 2008:12).

In total agreement with the fore going discussion, Anyanwu(1993) maintains that though the women might seem invisible and men visible in the socio-political arrangement of the Igbo societies, but the visibility of the men no matter how overwhelming does not suggest the subjugation of the women in Igbo traditional society (116). He further explicated the matter thus: ' ...right from the beginning, Igbo theory of life reckoned with the positive value of the input of female for the achievement of desired goals...that male -female visibility or participation in each aspect of Igbo life and culture was such that stressed the inevitability of the value of both sexes' (115-116). Lending credence to anyanwu's assumption, Nwakamnma (2009), notes that the Igbo societies did emphasize the primacy of the women, whether in a polygamous or monogamous relationship. According to him, the traditional Igbo architect and its spatial imperative gave large latitude to both the man and the women. It is not like 'the master bedroom' of western architecture (1-2).

Actually, the pre-colonial traditional Igbo egalitarian political institution accorded women more integral roles than exists now. Therefore, the seeming silencing of women's voices and the limiting of their exercise of leadership are not intrinsic to Igbo culture (Odoemene 2008:13). The seeming contemporary marginalization of the women socio-political powers is therefore an aftermath of the introduction of 'de-womanizing' colonial policies and medieval Christian notion of women's inferiority into Nigeria by British colonizers, Christian missionaries and the Nigerian male elites favoured by the change.

\section{Women and Peace Initiative in Igbo Traditional Society: A viable Option for Peace Building in Modem Africa}

Women have continued to be the worst hit in the situation of violent conflict and are also affected differently from men in the violent conflict. It is becoming unreasoningly accepted that women have unique opportunities for conflict resolution due to the unique role they play in society. Due to that role and their natural affinity towards peace building, women can likely contribute invaluably in peace process (Mutunga, 2008:368-9)

Actually, every society whether traditional or modern has always aspired to have a peaceful co-existence, however, this aspiration, if not guided and properly directed, might remain an utopia or mere dream, for now this is typical situation of the modern -post colonial Africa. However, the traditional African society, especially the Igbo people have an inbuilt network that guide and sustain this pristine peace aspiration of humanity. In the Igbo nation, many institutions and socio-political structure were the main stay of maintaining peaceful co-existence. The structure promotes the inculcation of social values that promote peace in the progenies. Here the roles of the traditional Igbo women become overt. These overt roles shall be discussed in this paper under four major headings, namely,

- Educational

- Mediatory

- Consolidatory

- Advisory

- The Educational Role of Igbo women in relation to Peace Initiative.

Beginning with educational role, we notice that Peace being a priceless commodity in the traditional Igbo society, was given primacy in the educational system of the Igbo traditional society. Thus, Ntahobari and Ndayiziga (2003) writes:

Education in the traditional social values was of prime importance. Children's education took place within the family through 'evening school' here through the medium of stories and proverbs, and as occasion presented, children were taught the virtues for living together peaceably under one roof. These included in particular moderation, solidarity, respect for the truth and willingness to work and strive, respect for authority, sense of honesty, modesty, tolerance, sense of goodness and kindness, love of one's neighbour, respect for life and so on (15).

This all-important role of educating the progenitors was the specific role of the women in the traditional society. Hence, Nwoye (2008) asserts, '...African traditional societies assigned to women the role of educator' (2). Women in the traditional Igbo society were transmitters of social and cultural values to their progeny and to the future generation. On the importance of social values, Fukuyama (199), call it social capital and defines at as a set of informal values and norms shared among members of a group that permit cooperation among them (16). Consequently, social capital warrants that members of a group expect others within the social setting to behave reliably and honestly and this in turn brings about trust with the group setting.

The implication of this type of educational system and method is pithily underscored in the fact that peace is not born but made and that the culture of peace was ingrained in the child through responsible upbringing (Nwoye, 2008:7) and socialization undertaken and supervised by mothers. The general observation in almost all traditional African societies is that peace building was taken seriously and it is established little by little in the young minds and moulded in the behavious and personality of the young people through the agency of the mother (Lihamba, 2003:111-113).

Notably, girls were trained specifically in their duties and responsibilities as women, who were to sustain the social fabrics of the society. This special training was carried on by the elderly women in the society. In the traditional Igbo society, from early childhood, each child 
was exposed to variety of songs, stories, proverbs and sayings directed by the mother or aunt, which was aimed at reducing conflict by exposing its negative effects on the world populations. The songs, stories, proverbs and sayings contain simple but clear messages and moral teachings ( Nwoye, 2003:7). The overall aim of the songs and stories as directed by the mothers' was to inculcate the expected moral values required by the society on the progeny. These stories and sayings contain but not limited the following social capitals

- Responsibility through reciprocity

- Honesty and loyalty through mutuality and deference

- $\quad$ Faith and compassion through inner strength and power

Some of these stories project greed and individual interest as major sources of conflict and consequently warn the young men and women against them. Certain myths given to the children in those days were meant to emphasize the fact that to avoid war can be an act of good leadership. Explicating on the educational role of women in other African cultures, Ndayi (2003) writes,

It was primarily the mother that had responsibility for the upbringing of children. Children especially when very young remained with their mothers, who would look after both boys and girls until they reach a given age ...there were strict rules to be complied with on how to dress, speak, eat, walk and sit especially for the girls (15).

In almost all traditional societies of Africa, it was noted that children live with mothers in the home of their birth, observing what is done, watching their parents and elderly ones and following their examples. This period of extended observation is supervised by the mother, who has her young children constantly at her side, giving them punishments scaled to their years, so that from an early age, children come to acquire an appetite for those human qualities, which are immensely invaluable to the society. Thus, the education of a daughter that reached the puberty age was a matter of on going concern for her mother, who had to prepare her properly for marriage, so that once a wife herself, she too would become a factor for stability and peace in her husband's family (Nwoye, 2008:16). In the same vein, Lihamba (2003) maintains that in Tanzanian traditional culture, women played a critical part in maintaining equilibrium in the society by bringing up their children as responsible members of the community. Women taught their daughters and sons, proper behaviours and the ethos of the society and impressed on them the importance of such values as honesty, uprightness and necessity to compromise. As such, women have been active promoters of harmony in the community, which can be referred to as 'culture of peace (26).

- The Mediatory Role of the Igbo Women in Conflict Situations

The mediatory role of women in Igbo society starts at the home or family level, being the nucleus of the society. Thus, the education of the girl-child is quite essential to preparing them to fulfilling this role. Noting that the primacy of peace was a cardinal property of the society, the education of girls was primarily based on peace, hence girls were expected to become as their mothers -the principal mediators at various levels of conflict (Mbede 2003:28). Thus in Igbo society, girls would ensure that their younger brothers and sometimes sisters were getting on well together, while their mothers were busy with their occupation or other major family or community affairs. It is the duty of older sisters to consoling, caressing, cradling, soothing and comforting the younger siblings. The family values and norms were transmitted to the younger ones through the agency of older sisters of the families. The girls taught their brothers and other children, the values of social sharing and social solidarity. They also show them how to provides and protect for the weaker and handicapped children. In this wise, the girls were regarded in most African societies and more particularly among the Igbo people as 'little mothers' preparing themselves among their brothers and younger sisters for the roles they would come to play in adult life in peace, mediation in the larger society ( Mbede, 2003:29).

The Igbo traditional system of education for the girls enabled them to supplement the roles played by their mothers by settling small conflict which would hinder good domestic management. The girl-mediator was expected to settle the petty quarrels among their siblings. Thus, whenever there was a dispute between two boys, the girlchild was asked to go and see what is happening between her brothers and settle the problem. In the Igbo traditional society, the first wife in a polygamous marriage arrangement was the chief peace mediator in the family. She was responsible for restoring peace and tranquility in a situation of conflict between the husband and other wives or husband brothers. She also ensures that there exists perfect harmony between the younger-in-laws and their wives. Mbede (2003) made the same striking discovery in Cameroon culture and reported his observations thus:

The first wives had great influence over her husband in at least two major ways-raised by her mother-inlaw(having been married young) she was initiated by the latter and entrusted with all family secrets ( this was the case among Beti in particular).Moreover, her position entitled her to be given official responsibility by her mother-in-law for relieving tension and ensuring a harmonious family relationship, moreover, her role as well as her personal qualities very often enabled the first wife to develop a strong personality, adding much charisma to her legislative status. The husband, who owed almost as much respect to her as to his own mother was conscious of this( 29).

Among the Igbo people of Eastern Nigeria, just like most African traditional societies, the first wives occupy central position in the socio-political arrangement of the communities. In fact, the first wife was often invited to deliberate with in the assemblies. Therefore, as a woman in what is fundamentally male forum, one of her major task 
was to soften sentences considered to be so serve or which could lead to crisis and disorder in the family or society.

Notably one of the fundamental principles upon which the Igbo society built was the sacred character of respect given to the elderly and particularly to the elderly women ( Mathey, Dejean, Deballe, Sapio, Koulammga, Moga 2003:35). Thus, in the traditional society, the elderly women were respected by all and as such they played key roles in the crises management in the traditional society. Therefore, whenever, conflict degenerated into armed violence, an appeal would usually be made by to the third party of a mature years to calm the tension and reconcile the combatant, such an appeal for mediation was usually made to a woman, who enjoyed the consideration and respect of all who know her. ( Nwoye 2006:17)

In a situation of manifest conflict in the traditional society, the oldest women of the clan would go to meet the opposing clan and interpose themselves between the fighters in order to make them see reason. If their entreaty seems ineffective, the women usually threatened to expose their nakedness or practically go down on their knees. In either case, the gesture signified a curse for those who bore the responsibility for such grave acts, owing to the enormity of respect the women commanded in those days, the warring parties will down their weapons before the fateful acts were accomplished by these women. However, in a situation of obstinacy and inanity of the warring parties, the old women, would make themselves naked and on their knees would crawl towards the combatants saying to them. 'We are your mothers. We do not want war. We do not want bloodshed. Do not fight with your brothers' They have sent us sue for peace ( Nwoye, 29). The older women in some Igbo traditional society employ desperate means to stop inter and intra clan wars. According to Nwoye (2008) and Mohammad (2003), these women form human chain, lined themselves up between the warring parties and refused to leave, until the two parties back down. Their immediate objective was to see to it that the two armies did not shoot at each other. A related objective was to bring in an alternative conflict resolution method based on dialogue $(32,103)$.

The paternal aunts also occupy a center piece in peace mediation and conflict resolution in the traditional society. The paternal aunts variously known as 'Umuada' 'Umuokpu' or Umu-mgboto' were responsible for the reconciliation of the individuals involved in the conflict. Umuada, which means native daughters, daughters of common make ancestors or daughters of the soil were indispensable in the Igbo socio-political arrangement. Therefore, in certain cases, were 'Umunna' the male counterpart of 'Umuada', fails to agree on any matter, the Umuada will step in to resolve the issue (Ene 2007:2). Notably, in a complex conflict of conjugal character, the intervention of Umuada was always a given. In such case the Umunna take the back seat and abide by the ruling of Umuada. Actually, Umuada were quite strict but fair in their intervention and peace enforcement process. The
Umuada in all Igbo culture were recognized as judges, peace brokers and enforcers. They were decent and dynamic in their decisions and actions to midwifing peace in the land of their birth. Thy were great arbiters.

- Consolidatory Role of Women in Peace Building Initiative in Traditional Igbo Society.

In any conflict resulting to bloodshed in the traditional Igbo society, the custom requires that serious pacifying steps be taken to broker peace between the two warring clans. Thus a traditional ceremony, known as 'blood money reparations' was organized between the two clans . In this ceremony a marriage involving the two clans was conducted. Here the women play significant role in this ritual of peace mediation and consolidation. The marriage arrangement was always between a man that lost his brother or close relative in the conflict and a girl from the opposing side. The aim of the marriage rite was to heal the wounds of war and cement a relationship between the warring clans. The general cliché among Igbo people is 'Where blood is shed, it must be soaked with birth fluid' ( Nwoye 2008 31). The implication of this action is that the married woman, who now becomes a type of 'peace offering' will give birth to sons, who will fill the void created by the men, who perished in the conflict. Furthermore, the marriage was designed to be an impregnable source of bond to the groups and thus minimize the possibilities of another conflict between the two clans Mathey (2003) reported of a similar practice in central African Republic thus,'In certain situations armed conflict between two clans, women used stratagem to bring hostility to end. They held meeting and chose the prettiest girl of marriageable age and give to the opposing clan as a token of peace'(42)

In this society as noted by the same author, the blood pact through marriage put immediate and final end to conflict, as the girl married to one of the heroes of the enemy clan now become a 'link' between her parents and her parents-in-law. The marriage, according to traditional logic constitute an inviolable alliance between the two villages involved in the conflict.

In the traditional Igbo society, the nature of exogamous marriage constitute a potent vector in the spread of peace. Over and above the union of the physical persons that were the wife and the husband, marriage was regarded as an alliance between two clans represented by each clan. Thus in the traditional society, the wife and the husband were duty bound to overcome the difficulties and conflict which might separate them in order to perpetuate this sacred alliance ( Mathey, 2003:45)

Furthermore, in a situation of armed conflict, women played both active and passive roles in the restoration and consolidation of peace in Igbo land. The women at this point become the initiator and agent of covenant relationship between the opposing parties. A pact usually operated in the resolution of conflict caused by a murder of a member of a clan member, when required, a female mediator was quickly sent to the family of the victim. If the 
meditation was effective, the two families meet to break the string beard of cut water yam, which signifies eternal sorority. Within the framework of passive peace making, a girl could be offered to the family of the victim as a form of reparation. This kind of blood pact not only put and end to the conflict between the descendants of the clan, with the two clans being intimately linked for life (Achebe, 1958:72).

- Advisory Role of Traditional Igbo Women in Peace Initiative.

Although the Igbo traditional society had a inbuilt mechanism that encouraged cohesiveness and peaceful coexistence, however, conflicts still erupt between families and between individual. In order to control the escalation of such conflicts, women were generally involved and in fact played significant roles. They played this role behind the screen in an advisory capacity. According to Nwoye (2008) within this structure, women played the more unobtrusive, yet leading substantive role, both in their families and within their own circle (27). There is a general revelation that in almost all Igbo communities, women exercised considerable influence over their husbands. However, such influence was forced to remain discreet as it was a controversial issue in the society, which could see it as weakness on the part of her husband. As a result, the wife was usually discreet in public but becomes the most influential adviser of her husband in the intimacy of the bedroom ( Nwoye, 2008:28).

In the Igbo traditional society, there was this practice, now antiquated where after sharing a family meal, the traditional wife reserved a small dish called, 'bed dish', which she gave to her husband at bed time. It was during this time intimate meal that confidential conversations took place between husband and wife. During this intimate conversation, the wife called her husband by the name of her first son or daughter and gave him advise on the basic facts of life ( Mathey 2003:39). This piece of advice would greatly influence the decisions, which the husband would latter take. Sometimes within the system, when a husband was faced with problem, he would not take immediate decision, until the following night, so that he could confer with his wife. By this advisory role, the women played major active part in strengthening social solidarity and harmony.

\section{Conclusion}

In spite of the usefulness of the Igbo traditional norms and values, the modern society has regarded them as inconsequential to human existence. Some of the major values that has been violated in the modern times, include but not limited to: 1 . The practice of extended family system, 2. Communal labour, 3. Mutual Respect and 4. The obligation to remain dignified. The loss of these and more traditional moral and values has brought about social decay to modern Igbo societies, without exception. Another major factor to the contemporary social decay is women's failure in the divine duty as social stabilizes and natural peace brokers. The reason behind this great failure that has become the great undoing of the modern African society is that women, have devoted more of their energy and life to their career than to their families, children and husband, who depend on her for guidance and direction. Against this backdrop, the education, care and nurture of the children and guidance to the husband are left to fate. The effect of this nature-duty neglect by the modern career African women is the great moral degeneration, which has become the observable behavior of the present day young people. Thus, when the women adjudicated their fundamental duty peace maintenance and conflict management, it then becomes normal that there is an upsurge of bloody conflicts and wars in the modern African society.

This work therefore underscores the fact that traditional definition of peace as freshness, health, well-being, which is antithetical to poverty, insecurity unemployment waywardness and all man-made misfortunes must be reinvented as a paradigm of modern peace study. In doing so, the role of women as mothers, wives and aunts must be re-imaged into the modern African socio-political structure, noting, particularly that women participated actively in the inculcation of culture of peace in the children and in the practice of effective conflict mediation among warring parties. The Igbo people, just as many other African societies, are aware that lasting peace does not grow in a vacum. In their view, health, peace feeds and grows on enduring human values ingrained in the children at tender age. Therefore, it is argued that sustainable peace cannot reign in the contemporary Africa, without first and foremost recovering of those fundamental values and norms upon which the traditional African society was built and nurtured.

Furthermore, if modern Africa states must experience peace, some of those traditional peace mediation methods that the women have applied in the past must be reassessed and with certain limited modification reintroduced in the modern peace building process. The paper strongly maintains that the panacea for bloody conflict in modern Africa lies in the readopting of the traditional method of conflict management as discussed in the body of this work. In the same direction, the modern education system, which purported to take over the role of responsible child upbringing, originally the reserve of the African women must be re-examined to make sure that it becomes a centre for successful transmission of peace values and policies. This paper therefore, asserts that in the training and educating of the African child, positive cultural values must occupy the centerpiece of the curricular, this is quite essential to getting back to the track. 


\section{References}

[1] Ademola, Faleti.S. (2007).'Theories of Social Conflict' Introduction to Peace and Conflict Studies in West Africa: Shedrack Gaya Best (ed) Ibadan: Spectrum Books.

[2] Achebe, Chinua, (1958). Things Fall Apart: London Hemeinam Educational Publication.

[3] Aeschylum, E.A. Seven Against Thebes. Translated by Murray Gibert (1980). London: George Allen.

[4] Afigbo Adiele, E. (1972). The Warrant Chiefs: Indirect Rules in Southeastern Nigeria 1891-1929, New York: Humanities Press

[5] Anyakaoha, Elizabeth .U. (2008). Extending the Frontier of Age-long Powers of Women in Southeast Nigeria for Grassroots Development. Unclassified material downloaded from $w w w / h t t p / h t m l / p d f$. Nigeria org. 28.09.08

[6] Anyanwu, U.D. (1993) 'Gender Question in Igbo Politics' in Anyanwu, U.D, and Aguwa, J.C.U. (eds) The Igbo and Traditional of politics. Enugu, Fourth Dimension.

[7] Banton, R.H. (1982). Christian Attitudes towards War and Peace: A Historical Survey and Critical Evaluation, Nashoule: Abingdon.

[8] Castilina, (1972). The Fragraments, California, Mary knees.

[9] Chinweizu, (1991). Anatomy of Female Power, Lagos: Peru..

[10] Clattopadhayay, Kamladeri,(2008). Women: The Comrade, www Gawhiwomen http/Edu org. retrieved 29.09.08

[11] Collier, J.F. (1974) "Women in Politics" in Rosaldo, M.Z and Langhene (eds) (1974) Women, Culture And Society. Stanford: University Press.

[12] Dine, G.U. (1983). Traditional Leadership as service among the Igbo of Nigeria: An Anthropological Approach. Rome: Pontifical University Laterance.

[13] Ejimofor, Lambeth .U. (1981). Dynamics of Igbo Democracy: A Behavioural Analysis of Igbo Politics in Aguiniyi Clan. Ibadan: IVP.

[14] Ene .M.O.(2007) The women in Igbo Culture. New Jeresy. Dortam Books

[15] Francis, David.J. 'Peace and conflict church: An African Overview of Basic Concepts' In Introduction to Peace and Conflict Studies in West Africa Edited Gaya Best, Ibadan: Spectrum.

[16] Fredl, E. (1975). Women and Men: An Anthropological View New York, Holt, linehast and Winston.

[17] Fukuyama, Francis, (1999). The Great Disruption: Human Nature and the Reconstruction of Social Order. London: Profile.

[18] Gerhand Kettel. (1938).The Concept of Peace in Old Testament, Nashville.: Noston Press

[19] Germane, A.W (1999). 'A Historical Commentary' In Theicydicies I. Oxford: OUP.
[20] Green, M.M. (1964). Ibo Village Affairs $\left(2^{\text {nd }} E d\right)$. London: Frank Cass

[21] Ibeanu, Oke. (2007). 'Conceptualizing Peace' Introduction to Peace And Conflict Studies In West Africa: Edited By Shedrack Gaya Best: Ibadan: Spectrum Books.

[22] Ifemesca, Chieka, (1979). Traditional Humane Living among the Igbo: A Historical Perspective Enugu: Fourth Dimeneum.

[23] Jeanne (1993). Woman and War. London: Zed Books.

[24] Karame,Kari (2004)(Ed). Gender and Peace Building in Africa. Norway: Norsk.

[25] Khan, Kanlana (2008). Peace and Religion (Unclassified Material) Retrieved From Www/Global Accmstitude/Http, May 13, 2008.

[26] Kusa, Daiyo .O. (2007). 'Gender, Peace and Conflict in Africa'.Introduction to Peace and Conflict Studies In West Africa: Edited By Shedrack Gaya Best: Ibadan: Spectrum.

[27] Lihamba .A. (2003) Women's Peace-Building And Conflict Resolution Skills, Morogoro Region -Tanzania Paris : UNESCO

[28] Mathey, M.J. Dejean T, Deballe, M, Soplo, R, Koulaning A. Moga, J, (2003). The Role Played by Women of central Africa Republic in the Prevention and Resolution of Conflicts. Paris :UNESCO.

[29] Myre, John .L. (1927). The Political Idea of Greek. New York: Colorodo

[30] Mutunya, Elizabeth (2008). 'Gender and Peace Process in Africa' In Introduction to Peace and Conflict Studies in West Africa (Ed) Shedrack Gaya Best (2008) Ibadan. Spectrum.

[31] Ngongo-Mbede, Valerie,(2003). The Traditional Mediation of Conflicts by Woman in Cameroon, France: UNESCO

[32] Ntahobani, Josephine and Ndayiziga, Basilissa (2003). The Role of Burundi Women In Peaceful Settlement Of Conflicts. Paris: UNESCO.

[33] Nwachukwu, C.B. (1993) "Universal Properties of Political System: The Case of the Igbo Anyanwu', U.D. And Aguwa, JCU (Eds) The Igbo And The Traditional Politics. Enugu. Fourth Dimension.

[34] Nwakanma, Obi (2008). Sex, Women and (HU)Woman Rights. Igbo Women Have A Special Place in Our Culture' The Newspaper, Honston, Nigeria Central Com The Black Business Journal. Vol. 10 No 15. (1-2).

[35] Nwoge, Miriam A.C. (2008). Role of Women in Peace Building and Conflict Resolution In African Traditional Societies: A Selective Review. Naurobi, Kemyatta University.

[36] Nwoye, Agatha M.C. (2009) Role of Women in PeaceBuilding And Conflict Resolution In African Traditional Societies: A Selective Review: Nainobi Kenyatta University Press.

[37] Odoemene, Akachi (2008) "(Re) Venturing Into The Public Sphere: A Historical Sociology Of "August Meeting" Among Igbo Women In Nigeria" Codesria: $12^{\text {th }}$ General 
Assembly On Govering Africa Public Sphere 07-11 December 2008. Yaoundé Cameroon.

[38] Ohivca, B. Bexley J. Warmark K. (Eds) (1995) Arm To Fight, Arm To Protect, Women Speak Out About Conflict. London Panos

[39] Olsson, Rouise (2001), 'Gender Mainstreaming in Practice: The United Nation Traditional Assistance Group in Nambia" In Olsson and Tryggested (Ed)London. Frank Cass.

[40] Okoro, Kingsley.N.(2008). "Alternative Feminism for Nigerian Women. The Gandhian Option" In African Journal of Religion. Culture and Society Vol. 2, No 1, June, 2008 (172-193)

[41] (2008)"Religion". A Vital Instrument for Global Peace" Contemporary Issues In Philosophical and Religious Discourse (Eds) Okoro, Kingsley And Kalu, Maculay.A. Port Harcourt Publimedia.
[42] Report (2002) Women, Peace And Security, Submitted By The UN Secretary General Pursuant To Security Council Resolution 1325 (2000)

[43] Uchendu, P.K. (1972). The Warrant Chiefs: Indirect Rules in Southeastern Nigeria 1891-1929. New York: Humanities Press.

[44] Uka, E.M. "Living Religion: Challenge Of Checking Violence Occasioned By Economic Globalization" A Paper Presented At The $9^{\text {th }}$ World Conference Of International Association For History Of Religion (IAHR) Held At Tokyo-Japan-March 23-30. 2005 (15-34)

[45] Weeks, Dully (1992). The Eight Essential Steps to Conflict Resolution. New York: Pitman The Richer. 